\title{
Control of Varroa Mite (Varroa destructor) on Honeybees by Aromatic Oils and Plant Materials
}

\author{
A. Al-Abbadi ${ }^{1}$ and I.K. Nazer ${ }^{2 *}$ \\ ${ }^{1}$ Department of Bioagricultural Technology, Faculty of Agricultural Technology, \\ Al-Balqa' Applied University, Al-Salt, Jordan. \\ ${ }^{2}$ Department of Plant Protection, Faculty of Agriculture, University of Jordan, \\ Amman, 11942, Jordan.
}
كا فحة ح لم I J فاروا (Varroa destructor) على نحل العسل باستخدام بعض الزيوت العطرية والأعشاب المحلية إحلية
أمل العبادي وإبراهيم الناظر

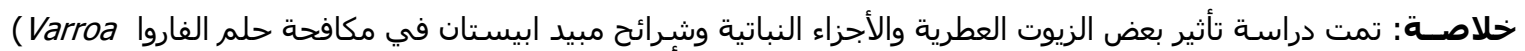
زئ日 destructor)

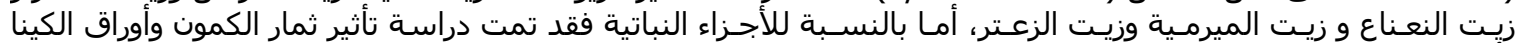

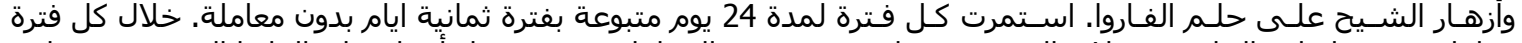

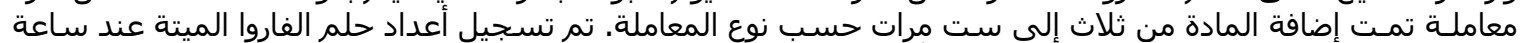

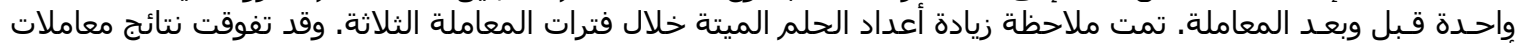

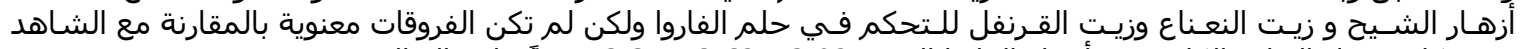

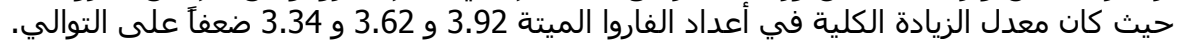

\begin{abstract}
The effect of several volatile plant oils, plant materials and fluvalinate (Apistan ${ }^{\circledR)}$ strips on the control of the mite Varroa destructor on honeybee (Apis mellifera L.) colonies was studied. The volatile oils were: clove, lavender, peppermint, sage, and thyme. The plant materials were: cumin fruits, eucalyptus leaves, and worm wood flowers. For each tested material, three treatment periods were carried out. Each period lasted for 24 days followed by eight days no-treatment. Within each treatment period, an average of three to six treatments were applied. Dead mites were counted one hour before and after each treatment. An increase in dead mites was recorded for the three treatment periods. It indicated that worm wood flowers, peppermint oil and clove oil treatments gave the best results in the control of Varroa mites but not significantly different than the control. The overall increase in the dead mites was 3.92, 3.62 and 3.34 fold, respectively.
\end{abstract}

Keywords: Varroa mite, honeybees, aromatic oils, weeds, Jordan.

B eekeeping is an important part of agriculture. There are thirty thousand modern hives in Jordan and about six hundred traditional clay hives (Ministry of Agriculture, 1997). Honeybee colonies are subject to infestation by insects, mites and diseases. The parasitic mite Varroa jacobsoni Oud. renamed as Varroa destructor (Anderson and Trueman), (Anderson and Trueman, 2000) is considered one of the most serious pests to beehives, causing great economic loss to the beekeeping industry (Baker and Peng, 1995). This mite can be found on adult bees, on the brood, and in hive debris. In a heavy infestation, pupae may not develop into adult bees. The adults that do emerge may weigh less than healthy bees (Shimanuki and Knox, 1991). Advanced infestations cause considerable damage to honeybee populations (Baker and Peng, 1995) resulting in a reduction of the quantity and quality of the colonies available for honey production and pollination (Spivak, 1997). In one apiary in the USA, out of 245 colonies only $28 \%$ (67 colonies) survived. It appeared that the 
death was caused by Varroa (Putman and Cochise, 1996). In Jordan, Varroa mite inflicted heavy damage in 1986. This led to the loss of 15,000 hives representing $50 \%$ of modern hives and most of the traditional ones (Ministry of Agriculture, 1986). The Ministry imported the acaricide Sencor and distributed it to Jordanian beekeepers in order to address the Varroa problem. Since then, beekeepers have used several acaricides e.g. bromopropylate, coumaphos, flauvalinate, amitraz and formic acid. In other countries beekeepers used different acaricides like amitraz, coumaphos, and fluvalinate (Ruijter, 1994). Due to the widespread misuse of chemical treatments, several cases of resistance have been reported (Elzen et al., 1998). Since Varroa mite has developed resistance to certain acaricides, it is of fundamental concern to look for new control agents (Dufol et al., 1991; Kraus et al., 1994; Lindberg et al., 2000).

In this research we investigated the possibility of using volatile plant oils and local plant materials for the control of Varroa mite on bees. These natural materials generally have no side effects on honeybees and are less hazardous to beekeepers.

\section{Materials and Methods}

EXPERIMENTAL HONEYBEE COLONIES: Two experiments were carried out. The first was conducted in Amman governorate at three locations (Na'ur, Yajouz and $\mathrm{Al}-$ Baqa') in the summer of 1997. The second one was in Al-Salt governorate at three locations (Al-Magareeb, AlAksam and Wadi-Al-Salt) in the summer of 1998. Both experiments had the same number of colonies, treatments and replications. Thirty colonies of hybrid Italian honeybees, Apis mellifera were used each summer, ten in each location were considered as a replicate. The chosen infected colonies were similar with approximately the same number of brood frames, each of one honey and pollen frames and headed by a one-year old queen. In each of the two experiments, the treatments were arranged in a randomized complete block design (RCBD).

TREATMENTS: Five volatile oils: clove (Syzigium romaticum), lavender (Lavandula coronopofolia), peppermint (Mentha piperita), sage (Salvia triloba) and thyme (Origanum syriacum) were tested for the control of Varroa mite. In addition, three plant materials: cumin fruits (Cuminum cyminum), eucalyptus leaves (Eucalyptus camadulentis) and worm wood flowers (Artemisia herba-alba) were tested for the control of Varroa at the same time. At each location, there were two colonies. One of them was treated with Fluvalinate, Apistan strips ${ }^{\circledR}$, and the other was left untreated for comparison. During each summer, there were three treatment periods, 24 days each for a total of 72 days. During each treatment period, the number of applications varied according to the tested material.
Before each period, there was an eight day period with no treatment application to count the number of the dead mites in each colony. The number of fallen mites was counted two times (four day interval) for each colony in each apiary during that period.

The treatments of colonies were carried out from 19 June to 30 September and from 15 May to 27 August in the summer of 1997 and 1998, respectively. The difference in timing was governed by infestation of colonies with the Varroa mite.

\section{METHODS OF APPLICATION:}

\section{Treatment with Volatile Oils}

Application of concentrated volatile oils was made three times during each treatment period, eight days apart as applied by Amrine et al. (1996). Florist foam blocks, were utilized as a carrier for the oils (Calderone and Spivak, 1995). A sample, $25 \mathrm{ml}$, of concentrated volatile oil was applied, which was enough to saturate four florist blocks $(2 \times 2 \times 2 \mathrm{~cm})$. The blocks saturated with the test material were distributed between the brood combs, inside the hive on the bottom board of the colony. After eight days, they were removed and replaced with new ones.

\section{Treatment with Plant Materials}

\section{i. Eucalyptus leaf-smoke}

One colony out of ten in each replication was treated with eucalyptus leaf-smoke. The colony was exposed to the smoke of ten grams of eucalyptus leaves as carried out by Shalaby et al. (1996). The leaves were placed in a lighted smoker with burlap, and fifteen puffs were blown inside the hive through the entrance. The entrance was blocked for fifteen minutes, and the colony was completely closed from all sides. The treatment of eucalyptus leaf-smoke was repeated every four days with six applications during each treatment period (24 days).

\section{ii. Worm wood and cumin}

Fifty grams of cumin fruits and $50 \mathrm{~g}$ of worm wood flowers were ground using a grinding machine as described by Abu-Zeid and Ghoniemy (1993). The powders for each of the two materials were placed on four pieces of porous cheese cloth and tied. The four samples were placed inside on the bottom board of the colony between the brood combs. In each location, one colony received worm wood flowers and one colony received cumin fruits. After eight days of application the tested material was removed and replaced with a new one. Three applications were made in each treatment period.

\section{Apistan strips}

One colony in each replicate was treated with Apistan ${ }^{\circledR}$, which was used at the rate of one strip/five 
brood combs (Bach, 1995). The strip was inserted between the brood combs. One application of these strips per colony was made every 24 days, with a total of three applications in each summer.

Mite Collection Device: Mite collection devices were locally made, and consisted of a rectangular wooden frame of $40.5 \mathrm{~cm}$ length, $25 \mathrm{~cm}$ wide and $2 \mathrm{~cm}$ high. In the open space of the frame, a movable wooden board was placed on which a piece of rigid white paper was fixed by pins and smeared with a thin layer of Vaseline to capture the fallen mite (Colin, 1990). A wire mesh $(2 \mathrm{~mm})$ screen was placed on the upper part of this device, to allow the dead mites to fall through onto the movable wooden board. This screen would not allow bees to pass through and thus prevented them from removing the dead mites outside the colony (Calderone and Spivak, 1995). The Vaseline-treated paper was taken every four days to count the number of fallen mites, and was replaced with new Vaseline smeared paper. The mite collection device was fixed at the lower of the hive after removing the bottom base of the hive. The fixing and removable side of the wooden frame in each hive was at the back of the hive, to avoid honeybee's disturbance.

\section{Number of Fallen Dead Varroa Mites}

To evaluate the effectiveness of the control agents, the number of mites captured by the collecting device was counted and recorded for each colony. The number of fallen mites was counted every four days.

\section{Statistical Analysis}

The number of the dead (fallen) mites was used to calculate the folds of dead Varroa. Results were statistically analyzed using Duncan's Multiple Range Test (DMRT).

The folds of dead Varroa after treatment that determined which treatment was superior over other treatments during each treatment period in each summer, were calculated. The average number of fallen mites for the pretreatment period was divided by the average number of fallen mites during one treatment period (Tables 1 and 2). The most effective application period of treatment to control Varroa was calculated by taking the total number of fallen mites collected during one treatment period, divided by the total number of fallen mites collected in each reading (each four days), multiplying by $100 \%$. This equation gave the percent mortality of Varroa (Tables 3 and 4).

\section{Results}

EFFECTIVENESS OF TESTED MATERIALS: Results presented in Table 1 show that in the first treatment period (FTP), there were no significant differences among
TABLE 1

Means of folds of fallen Varroa mites for each of three treatment periods during summer of 1997.

\begin{tabular}{lccc}
\hline Treatments & \multicolumn{1}{c}{ First* } & Second & Third \\
\hline Clove oil & $2.61 \mathrm{a} \pm 1.62 * *$ & $0.78 \mathrm{~b} \pm 0.49$ & $5.32 \mathrm{a} \pm 3.83$ \\
Lavender oil & $1.77 \mathrm{a} \pm 0.46$ & $0.70 \mathrm{~b} \pm 0.21$ & $2.18 \mathrm{a} \pm 0.61$ \\
Peppermint oil & $3.83 \mathrm{a} \pm 1.87$ & $0.79 \mathrm{~b} \pm 0.15$ & $2.79 \mathrm{a} \pm 2.18$ \\
Sage oil & $3.21 \mathrm{a} \pm 1.38$ & $0.79 \mathrm{~b} \pm 0.43$ & $0.85 \mathrm{a} \pm 0.49$ \\
Thyme oil & $2.79 \mathrm{a} \pm 0.88$ & $0.58 \mathrm{~b} \pm 0.16$ & $1.07 \mathrm{a} \pm 0.32$ \\
Cumin fruit & $1.58 \mathrm{a} \pm 0.46$ & $0.59 \mathrm{~b} \pm 0.34$ & $4.07 \mathrm{a} \pm 1.92$ \\
Eucalyptus leaves & $1.72 \mathrm{a} \pm 0.61$ & $0.58 \mathrm{~b} \pm 0.06$ & $1.88 \mathrm{a} \pm 0.59$ \\
Worm wood flowers & $3.85 \mathrm{a} \pm 1.82$ & $1.00 \mathrm{~b} \pm 0.41$ & $4.67 \mathrm{a} \pm 2.23$ \\
Apistan strips & $3.18 \mathrm{a} \pm 1.40$ & $1.03 \mathrm{~b} \pm 0.55$ & $1.35 \mathrm{a} \pm 0.25$ \\
Control & $1.43 \mathrm{a} \pm 0.21$ & $3.40 \mathrm{a} \pm 2.30$ & $3.43 \mathrm{a} \pm 2.94$ \\
\hline * Each treatment period lasted for 24 days, with six readings. \\
** Means within columns with the same letters are not significantly different \\
according to DMRT at 5 \% level.
\end{tabular}

TABLE 2

Means of folds of fallen Varroa mites for each of three treatment periods during summer of 1998.

\begin{tabular}{|c|c|c|c|}
\hline Treatments & First* & Second & Third \\
\hline Clove oil & $3.77 \mathrm{ab}^{* *} \pm 0.07$ & $1.50 \mathrm{ab} \pm 0.63$ & $6.07 \mathrm{a} \pm 1.22$ \\
\hline Lavender oil & $4.38 \mathrm{ab} \pm 1.74$ & $0.91 \mathrm{ab} \pm 0.25$ & $3.69 \mathrm{a} \pm 0.92$ \\
\hline Peppermint oil & \pm 1.56 & $2.15 \mathrm{ab} \pm 0.60$ & $2.96 a \pm 1.68$ \\
\hline Sage oil & $2.22 \mathrm{ab} \pm 0.85$ & $3.38 \mathrm{ab} \pm 1.68$ & $3.93 a \pm 1.22$ \\
\hline Thyme oil & \pm 1.22 & $3.68 \mathrm{a} \pm 1.40$ & $2.74 a \pm 0.70$ \\
\hline Cumin fruit & $3.70 \mathrm{ab} \pm 1.29$ & $2.12 \mathrm{ab} \pm 1.47$ & $1.95 \mathrm{a} \pm 0.53$ \\
\hline Eucalyptus leaves & \pm 0.22 & $1.13 \mathrm{ab} \pm 0.71$ & $3.95 \mathrm{a} \pm 1.71$ \\
\hline Worm wood flowers & \pm 2.32 & $2.04 \mathrm{ab} \pm 0.89$ & $6.38 \mathrm{a} \pm 3.55$ \\
\hline Apistan strips & \pm 1.51 & $3.50 \mathrm{ab} \pm 0.58$ & $6.82 \mathrm{a} \pm 3.34$ \\
\hline Control & $1.69 \mathrm{ab} \pm 0.99$ & $0.69 \mathrm{~b} \pm 0.07$ & $3.10 \mathrm{a} \pm 1.55$ \\
\hline
\end{tabular}

*Each treatment period lasted for 24 days, with six readings.

**Means within columns with the same letters are not significantly different according to DMRT at $5 \%$ level.

TABLE 3

Comparison of means of folds of fallen Varroa mite for all treatments during summers of 1997 and 1998.

\begin{tabular}{|c|c|c|}
\hline \multirow{2}{*}{ Treatments } & \multicolumn{2}{|c|}{$\begin{array}{l}\text { Means of means of folds of fallen mites } \\
\text { for three treatment periods* }\end{array}$} \\
\hline & Summer 1997 & Summer 1998 \\
\hline Clove oil & $2.90 \mathrm{a}^{* *} \pm 1.38$ & $3.78 \mathrm{ab} \pm 0.77$ \\
\hline Lavender oil & $1.55 \mathrm{a} \pm 0.32$ & $2.99 \mathrm{ab} \pm 0.78$ \\
\hline Peppermint oil & $2.47 \mathrm{a} \pm 0.94$ & $3.58 \mathrm{ab} \pm 0.86$ \\
\hline Sage oil & $1.62 \mathrm{a} \pm 0.59$ & $3.18 \mathrm{ab} \pm 0.69$ \\
\hline Thyme oil & $1.48 \mathrm{a} \pm 0.43$ & $3.60 \mathrm{ab} \pm 0.76$ \\
\hline Cumin fruit & $2.08 \mathrm{a} \pm 0.78$ & $2.59 \mathrm{ab} \pm 0.51$ \\
\hline Eucalyptus leaves & $1.40 \mathrm{a} \pm 0.32$ & $2.09 \mathrm{ab} \pm 0.61$ \\
\hline Worm wood flowers & $3.17 \mathrm{a} \pm 1.01$ & $4.68 \mathrm{ab} \pm 1.42$ \\
\hline Apistan Strips & $1.85 \mathrm{a} \pm 0.56$ & $5.16 \mathrm{a} \pm 1.77$ \\
\hline Control & $2.75 \mathrm{a} \pm$ & $1.83 b \pm 0.69$ \\
\hline
\end{tabular}

*Means for the three treatment periods with six readings for each period.

**Means within rows with the same letters are not significantly different according to DMRT at $5 \%$ level.

the treatments. There was a 3.18 fold increase in the dead mites after treatment with Apistan ${ }^{\circledR}$ compared to a 1.43 fold increase in the control treatment. Several 
TABLE 4

Means of three treatment periods of mortality of Varroa mite for each of six readings obtained at four day intervals for summer 1997.

\begin{tabular}{|c|c|c|c|c|c|c|}
\hline \multirow{3}{*}{ Treatments } & \multicolumn{6}{|c|}{ Mortality Means $(\%) \pm$ SE } \\
\hline & \multicolumn{6}{|c|}{ Reading } \\
\hline & $(1)$ & $(2)$ & (3) & $(4)$ & $(5)$ & (6) \\
\hline Clove oil & $15.54 \mathrm{a}^{*} \pm 4.55$ & $12.48 \mathrm{a} \pm 2.89$ & $19.97 \mathrm{a} \pm 3.36$ & \pm 2.29 & $16.79 \mathrm{a} \pm 2.87$ & $19.90 \mathrm{a} \pm 5.13$ \\
\hline Lavender oil & $7.33 c \pm .1 .33$ & $12.61 b c \pm 2.60$ & $14.68 \mathrm{abc} \pm 1.98$ & \pm 6.01 & $19.46 \mathrm{ab} \pm 2.62$ & $24.14 \mathrm{a} \pm 4.69$ \\
\hline Peppermint oil & $15.88 \mathrm{a} \pm 4.51$ & $16.91 \mathrm{a} \pm 3.96$ & $18.14 \mathrm{a} \pm 3.37$ & \pm 2.72 & $13.00 \mathrm{a} \pm 3.40$ & $11.22 \mathrm{a} \pm 2.90$ \\
\hline Sage oil & $14.07 \mathrm{a} \pm 2.60$ & $16.46 \mathrm{a} \pm 2.36$ & $17.74 \mathrm{a} \pm 2.67$ & \pm 2.46 & $19.72 \mathrm{a} \pm 2.55$ & $13.48 \mathrm{a} \pm 2.57$ \\
\hline Thyme oil & \pm 4.17 & $16.67 \mathrm{a} \pm 2.82$ & $17.13 \mathrm{a} \pm 2.51$ & \pm 2.48 & $19.24 \mathrm{a} \pm 3.47$ & $15.56 \mathrm{a} \pm 2.62$ \\
\hline Cumin fruit & \pm 3.39 & $23.29 \mathrm{a} \pm 3.82$ & $15.36 \mathrm{a} \pm 2.72$ & $14.46 \mathrm{a} \pm 2.85$ & $13.57 \mathrm{a} \pm 2.51$ & $16.27 \mathrm{a} \pm 3.92$ \\
\hline Eucalyptus leaves & $11.13 \mathrm{c} \pm 1.99$ & $13.79 \mathrm{cb} \pm 2.21$ & $14.60 \mathrm{bc} \pm 2.20$ & $17.62 \mathrm{abc} \pm 2.33$ & $18.79 \mathrm{ab} \pm 2.59$ & $24.08 \mathrm{a} \pm 2.52$ \\
\hline Worm wood flowers & \pm 6.64 & $17.94 \mathrm{a} \pm 3.85$ & $19.98 \mathrm{a} \pm 6.13$ & $14.88 \mathrm{a} \pm 4.46$ & $13.00 \mathrm{a} \pm 4.28$ & $13.77 \mathrm{a} \pm 4.63$ \\
\hline Apistan Strips & $11.80 \mathrm{~b} \pm 2.60$ & $20.87 \mathrm{a} \pm 3.03$ & $16.84 \mathrm{ab} \pm 1.70$ & $16.63 \mathrm{ab} \pm 2.09$ & $20.17 \mathrm{a} \pm 1.96$ & $13.70 \mathrm{ab} \pm 2.43$ \\
\hline Control & $13.98 \mathrm{ab} \pm 1.81$ & $13.61 \mathrm{ab} \pm 2.92$ & $15.53 \mathrm{ab} \pm 1.73$ & $24.72 \mathrm{a} \pm 5.63$ & $20.63 a b \pm 5.35$ & $11.47 \mathrm{~b} \pm 3.57$ \\
\hline
\end{tabular}

*Means within rows with the same letters are not significantly different according to DMRT at $5 \%$ level.

\section{TABLE 5}

Means of three treatment periods of mortality of Varroa mite for each of six readings obtained at four day intervals for summer 1998.

\begin{tabular}{|c|c|c|c|c|c|c|}
\hline \multirow{4}{*}{$\begin{array}{l}\text { Treatments } \\
\text { Clove oil }\end{array}$} & \multicolumn{6}{|c|}{ Mortality Means $(\%) \pm \mathrm{SE}$} \\
\hline & \multicolumn{6}{|c|}{ Reading } \\
\hline & \multirow{2}{*}{$\frac{(1)}{22.69 a^{*} \pm 1.93}$} & $(2)$ & $(3)$ & (4) & $(5)$ & \multirow{2}{*}{$\frac{(6)}{4.99 c \pm 0.62}$} \\
\hline & & $25.22 \mathrm{a} \pm 1.91$ & \pm 2.46 & $14.62 b \pm 2.05$ & $7.90 \mathrm{c} \pm 0.83$ & \\
\hline Lavender oil & $23.04 \mathrm{a} \pm 2.78$ & $25.30 \mathrm{a} \pm 1.76$ & $23.37 \mathrm{a} \pm 3.15$ & $12.36 \mathrm{~b} \pm 0.67$ & $8.93 b \pm 1.80$ & $7.31 \mathrm{~b} \pm 1.11$ \\
\hline Peppermint oil & $23.10 \mathrm{a} \pm 1.45$ & $22.77 \mathrm{a} \pm 2.03$ & $22.78 \mathrm{a} \pm 2.92$ & $13.04 \mathrm{~b} \pm 1.40$ & $10.17 b \pm 1.29$ & $12.00 \mathrm{~b} \pm 1.68$ \\
\hline Sage oil & $21.16 \mathrm{ab} \pm 3.57$ & $18.54 \mathrm{abc} \pm 1.19$ & $24.14 \mathrm{a} \pm 3.22$ & $15.36 \mathrm{bc} \pm 1.73$ & $12.90 \mathrm{~cd} \pm 0.91$ & $7.93 \mathrm{~d} \pm 0.96$ \\
\hline Thyme oil & $21.21 \mathrm{ab} \pm 2.11$ & $23.30 \mathrm{a} \pm 2.41$ & $17.28 b c \pm 1.35$ & $15.07 \mathrm{~cd} \pm 1.64$ & $12.52 \mathrm{~cd} \pm 1.82$ & $10.51 \mathrm{~d} \pm 2.07$ \\
\hline Cumin fruit & $25.17 \mathrm{a} \pm 2.14$ & \pm 2.14 & $23.59 \mathrm{a} \pm 2.79$ & $12.53 \mathrm{~b} \pm 1.10$ & $7.97 \mathrm{bc} \pm 1.49$ & $6.32 \mathrm{c} \pm 1.44$ \\
\hline Eucalyptus leaves & $23.57 \mathrm{a} \pm 3.87$ & \pm 2.52 & \pm 5.30 & $11.76 \mathrm{~b} \pm 1.85$ & $10.46 b \pm 1.97$ & $8.10 b \pm 1.64$ \\
\hline Worm wood flowers & $18.67 \mathrm{ab} \pm 2.07$ & \pm 3.34 & \pm 6.17 & $12.52 b c \pm 1.28$ & $09.88 \mathrm{bc} \pm 1.37$ & $8.50 \mathrm{c} \pm 2.17$ \\
\hline Apistan Strips & $22.12 \mathrm{a} \pm 2.28$ & \pm 0.88 & $25.41 \mathrm{a} \pm 3.64$ & $13.06 \mathrm{~b} \pm 0.90$ & $11.30 \mathrm{~b} \pm 1.54$ & $8.13 b \pm 1.64$ \\
\hline Control & $22.03 \mathrm{a} \pm 2.87$ & \pm 3.38 & $15.93 \mathrm{ab} \div 0.89$ & $13.98 \mathrm{~b} \pm 1.37$ & $14.28 \mathrm{~b} \pm 2.20$ & $12.33 b \pm 1.77$ \\
\hline
\end{tabular}

*Means within rows with the same letters are not significantly different according to DMRT at $5 \%$ level.

treatments were better but not significantly different than Apistan ${ }^{\circ}$. Worm wood flowers, peppermint oil and sage oil gave $3.85,3.83$, and 3.21 folds, respectively over the control (1.43). The other treatments gave better results than the control. In the second treatment period (STP), mortality in the control was significantly higher than all other treatments (Table 1). In the Apistan ${ }^{\circ}$ and worm wood flower treatments, the trend of dead mites did not change after treatment. During this period, the applied agents showed lower apparent effects on Varroa, as compared to control treatment that could be attributed to the build up of the Varroa population at this period. This was due to the fact that the colonies were not treated with any control agent. In the third treatment period (TTP), no significant differences were found. However, clove oil, worm wood flowers and cumin fruit treatments resulted in 5.32, 4.67, and 4.07 folds of dead mites, respectively as compared to the control treatment ( 3.43 folds). All treatments gave better results than Apistan $®$ except for sage and thyme oil.

Comparison among the means of folds of the three treatment periods for summer 1997 (Table 3) resulted in no significant differences among the treatments. However, worm wood flowers and clove oil gave the highest folds of dead mites after treatment, 3.17 and 2.90 folds, respectively. The peppermint oil and cumin fruits treatment resulted in 2.47 and 2.08 folds of dead mites, respectively. However, this increase was lower than the control treatment (2.75), but higher than Apistan ${ }^{\circledR}$ (1.85) (Table 3).

The results for summer 1998 (Table 2) indicated that in the FTP, peppermint oil and worm wood flower treatments significantly increased the dead mites as compared with eucalyptus leaves, but they were at the same level of significance with all other treatments. In the STP, thyme oil was significantly superior (3.68) over the control treatment $(0.69)$ in the dead fallen mites, but it was similar to other treatments. In the TTP, there were no significant differences. The folds of dead Varroa were approximately the same in the case of Apistan ${ }^{\circledR}$, worm wood flower and clove oil treatments, 6.82, 6.38 and 6.07 , respectively.

The means of folds of the treatment periods (Table 3) indicate that treatment with Apistan ${ }^{\circledR}$ was 
superior but not significantly different than cumin fruits, eucalyptus leaves and the control treatment. However, the other treatments were significant, as Apistan $^{\circledR}$, in their effectiveness for killing mites. During the three periods of treatments, the means of folds obtained from the control treatment was 1.83.

The EFFeCtive Period of APPliCATION: Results for summer 1997 (Table 4) indicated that the percent mortality means of mites for clove oil, peppermint oil, sage oil, thyme oil, cumin fruits and worm wood flower treatments were not significantly different among all readings. However, in case of the lavender oil treatment the fourth and the sixth readings were significantly superior over the first and the second readings, but they were at par with the other levels. Treatment with eucalyptus leaf-smoke showed the highest percent mortality means of mites after the sixth application, which was significantly superior over the first, second and third readings. However, they were at par with the other readings. The second and the fifth readings of the percent mortality means of mites for Apistan ${ }^{\circledR}$ treatments were significantly superior over the first reading, but they were at par with other readings.

According to the time of application, the result of comparison of each two readings in each application indicated that the second reading of the percent mortality means of mites was higher than the first one in the case of lavender oil, peppermint oil, sage oil, thyme oil, cumin fruits, eucalyptus leaves and Apistan ${ }^{\circledR}$ strips.

Results from summer 1998 (Table 5) showed that the first, second and the third readings of the percent mortality means of mites were significantly superior over the other readings in case of clove oil, lavender oil, peppermint oil, cumin fruits, eucalyptus leaves and Apistan ${ }^{\circledR}$ strips treatments. However, results of sage oil treatment indicated that the third reading of percent mortality means of mites was significantly superior over the fourth, the fifth and sixth readings. On the other hand, with thyme oil, the second reading of percent mortality means of mites was significantly superior over all other readings except the first one. Treatment with worm wood flowers showed that the second and the third readings of the percent mortality means of mites were significantly superior over the fourth, the fifth and the sixth readings, but they were at par with the first reading.

With regards to the time of application (i.e. first, second or third application), the results indicated that the second reading of the percent mortality means of mites was higher than the first one for clove oil, lavender oil, thyme oil and worm wood flowers. However, for all treatments, the third reading of the percent mortality means of mites was higher than the fourth one, and the fifth reading was higher than the sixth one.

\section{Discussion}

According to Baker (1988), the infestation rate of Varroa depends on climate, the physiological stage of honeybee and Varroa mite, presence or absence of drone cells and the hive itself. The efficiency of any control agent depends on it's activity and on the conditions prevailing inside the hive at the time of application.

During FTP (June 27 to July 21, 1997), there was a higher number of younger bees and drones, which are usually preferable to Varroa than other honeybee stages and castes (Winston, 1995). At the same time, the temperature was high enough $\left(30^{\circ} \mathrm{C}\right)$ to hasten Varroa to leave the brood cell to the adult bees. This is in agreement with Szabo and Walker (1996). These conditions caused a higher number of the infested bees to be exposed to the control agents, which resulted in a higher number of fallen mites (Table 1).

During the STP (July 29 to August 22), the applied agents showed lower apparent effects on Varroa compared to that of the FTP (Table 1). However, in the control treatment there was a continuous increase in the number of dead Varroa during the four day interval reading (Tables 1 and 4) and reached a mean of 3.40 folds. This increase could be attributed to the buildup of the Varroa population at this period. This was due to the fact that the colonies were not treated with any control agent. Moreover, during this period (STP), there was a high number of open brood cells, which were ready for capping. This provided a suitable chance for Varroa to escape the injuries of the control agents by entering these cells (Shalaby et al., 1996). These results indicate that the control agents could not penetrate the brood capping. In other words, their effects were mainly on the adult mite attached to adult bees.

During the TTP (August 30 to September 23), the means of increased folds of the fallen mites for the applied control agents, showed better results than FTP and STP. During the TTP, the temperature decreased to $17^{\circ} \mathrm{C}$ and honeybees formed clusters with a lack of brood, a condition which was observed through the pattern of Varroa falling on the sticky paper. This was not random. The fallen mites were concentrated directly beneath the clustered bees. Similar results were reported by Shalaby et al. (1996). All previous described conditions provided a suitable environment to expose Varroa mites directly to the volatile oils and plant materials.

Comparing the results obtained during each of the three periods (Table 1) indicates that some of the tested volatile oils and plant materials showed better results at certain periods but not through the three periods. This could be attributed to the life cycle of the honeybee and mite. Worm wood flowers, peppermint oil and sage oil treatments gave better results during the FTP, where as 


\section{AL-ABBADI AND NAZER}

clove oil, worm wood flowers and cumin fruit gave better results during the TTP (Table 1).

\section{Conclusions}

From the results obtained from this work, it can be concluded that worm wood flowers, clove oil and peppermint oil can be considered promising agents for the control of Varroa destructor. Good results can be obtained when the above materials are used two to three times each month during the infestation period. Effective time of application depends on the mite level of infestation and the life cycle of the mite. The natural control agents used in this work, seem to have no adverse effects on bees.

\section{Acknowledgments}

The authors wish to thank the Deanship of Scientific Research at the University of Jordan for partial financial support. Thanks are also due to beekeepers for their cooperation. Special thanks go to Prof. F. Al-Mohammady for his help in the statistical analysis.

\section{References}

Abu-Zied, M. J. and H.A. Ghoniemy. 1993. Evaluation the role of two natural substances for the controlling of Varroa jacobsoni infesting honeybee colonies. Egypt Journal of Applied Sciences 8(20):295300.

Amrine, J.W., J.R. Terry, A. Stasny, and R. Skidmore. 1996. New mite controls investigated. American Bee Journal 136(9):652-653.

Anderson, D. L. and J.W.H. Trueman. 2000. Varroa jacobsoni (Acari: Varroidea) is more than one species. Entomology Abstracts 31(10): 9507-Z31.

Bach, J. 1995. Don't abuse Apistan. Bee Culture 123(10):590-593.

Baker, M.D. 1988. Variability and biotypes of Varroa jacobsoni Oudemans. American Bee Journal 128(8):567-568.

Baker, M.D. and C.Y.S. Peng. 1995. Varroa jacobsoni and Tropilaelaps clareae: A perspective of life history and why Asian bee mites preferred European honeybees. American Bee Journal 135(6):415-420.

Calderon, N.W. and M. Spivak. 1995. The successful management of the parasitic mite, Varroa jacobsoni in colonies of the honeybee, Apis mellifera, with natural products. Wisconsin Badger Bee, USA.

Colin, M.E. 1990. Essential oils of labiatea for controlling honeybee varroosis. Journal of Applied Entomology 110:19-25.

Dufol, M.F., A.M. Viuales, and C.S. Acedo. 1991. Comparative tests of Fluvalinate and Flumethrin to control Varroa jacobsoni Oud. Journal of Apicultural Research 30(2):103-106.

Elzen, P.J., F.A. Eischen, J.B. Baxter, J. Pettis, G.W. Elzen, and W.T. Wilson. 1998. Fluvalinate resistance in Varroa jacobsoni from several geographic locations. American Bee Journal 138(9):674676.

Kraus, B., N. Koeniger, and S. Fuchs. 1994. Screening of substances for their effect on Varroa jacobsoni; attractiveness, repellency, toxicity and masking effects of ethereal oils. Journal of Apicultural Research 33(1):34-43.

Lindberg, C.M., A.P. Melathopoulos, and M.L. Winston. 2000. Laboratory evaluation of miticides to control Varroa jacobsoni (Acari: Varroideae), a honeybee (Hymenoptera: Apidae) parasite. Journal of Economic Entomology 93(2):189-198.

Ministry of Agriculture. 1986. A Yearly Survey of Apiary Conditions in Jordan. Amman, Jordan. pp.2.

Ministry of Agriculture. 1997. A Yearly Survey of Apiary Conditions in Jordan. Amman, Jordan. pp.2.

Putman, M.B. and A.Z. Cochise. 1996. Mites and bees. Bee Culture 124(6):328.

Ruijter, A.D. 1994. Issues in the control of Varroa infestation. In: New Perspective on Varroa, A. Matheson (Editor), 24-26. International Bee Research Association. Cardiff (UK).

Shalaby, A.A., S.I. Yousif-Khalil, S.M.A. El-Shakaa, and E.Z. Matter. 1996. Efficiency of some control agents against Varroa mites infesting honeybee colonies. Zagazig Journal of Agricultural Research 23(6):113-130.

Shimanuki, H. and D.A. Knox. 1991. Diagnosis of Honeybee Diseases. USDA, Washington D.C., USA.

Spivak, M. 1997. Honeybee hygienic behavior as a defense against Varroa jacobsoni mites. Resistant Pest Management 9(2):22-24.

Szabo, T.I. and C.R. Walker. 1996. Rate of infestation of Honeybee colonies by Varroa jacobsoni. American Bee Journal 136(6):447-448.

Winston, M.1995. Pesticide Resistance. Bee Culture 123(7):389-390.

Received July 2002.

Accepted November 2002. 